Emerging vacuums of strategic planning: An exploration of reforms in Finnish spatial planning

Jonne Hytönen* and Toni Ahlqvist

Jonne Hytönen

Geography Research Unit, University of Oulu, Finland

P.O. Box 8000, FI-90014 University of Oulu

jonne.hytonen@oulu.fi, +358407411378

Toni Ahlqvist

Finland Futures Research Centre, University of Turku, Finland

Turku School of Economics, FI-20014 University of Turku

toni.ahlqvist@utu.fi, +358405737398

*corresponding author

This is an Accepted Manuscript of an article published by Taylor \& Francis in European Planning Studies on 14 Feb 2019, available online:

https://doi.org/10.1080/09654313.2019.1580248. 


\section{Emerging vacuums of strategic planning: An exploration of reforms in Finnish spatial planning}

The paper offers a theory-based evaluation of the ongoing reforms in the Finnish spatial planning regime. The paper argues that Finnish planning is moving in a reactive and market-driven direction. This development is not being brought about solely through a direct decrease in public discretionary powers in planning, but is also unfolding indirectly through a process of rescaling in the spatial planning regime. These processes increase municipal autonomy in relation to other planning scales, despite problems observed in the municipality-centred market-driven planning orientation. The resulting reduction in manoeuvring room in public planning is conceptualized in the paper as expanding vacuums of strategic planning. Building on concepts from the literature on state transformation theory and scale theory, the paper draws together theoretical and empirical conclusions from several case studies conducted in close-to-administration projects.

Key words: vacuum of strategic planning, market-reactivity, neoliberalization, spatial planning, Finland 


\section{Introduction}

Municipalities play a peculiar role in Finnish spatial planning. In Finland, municipalities have equal planning powers, regardless of their size: the smallest municipalities, with less than 1000 inhabitants, carry the same planning duties, responsibilities and freedoms as the capital city Helsinki, with ca. 640000 inhabitants. Whereas the biggest cities have rather strong traditions and expertise in public land use planning, the smallest and many middle-sized municipalities often lack sufficient planning resources (see Puustinen et al., 2013; Hytönen, Kotavaara \& Ahlqvist, 2018). Another essential feature of the Finnish land use planning system is that official plans can only be made by public institutions. In an international comparison, the Finnish municipalities have held remarkably strong planning autonomy in relation to the central government (Prusi, 2013). In addition, there is no directly elected, institutionally strong, political organ between the central government level and the municipal level: the regional plans, made by the 18 regional councils ${ }^{1}$, are realized under municipal steering. Thus the planning monopoly, so to say, is firmly in the (public) hands of the municipalities. These features set the framework for strategic spatial planning in the state as well as in the emerging city-regions.

Due to recent changes in the Land Use and Building Act in Finland, the municipalities gain even more autonomy (Government Bill 251/2016). The changes reduce state power in planning, restrict planners' capacity to regulate short-sighted market activities, and change the position of municipalities in relation to market actors. Growth-stimulation in planning has a long history in Finland, starting from the post-war decades (Mattila, 2017), and Finnish planning has traditionally prioritized economic development, even privileging specific construction companies, for decades. However, with respect to this growth-stimulation tendency, the recent changes bring new features to the spatial planning culture that need to be discussed: Finnish planners are increasingly forced to shift the planning focus towards 
reactive facilitation and aggregation of particular private interests (cf. Puustinen, Mäntysalo \& Jarenko, 2017). We interpret this process as a transformation of planning culture from longterm welfarist planning towards local reactive practices (cf. Allmendinger \& Haughton, 2013).

We wish to contribute to the discussion on neoliberalization of planning by analyzing the impacts of these recent and emerging changes in the Finnish spatial planning regime. We argue that these changes hinder the institutional capacity of spatial planning to address complex, long-term issues. We provide a state theoretical perspective towards planning, building on state transformation literature (e.g. Brenner, 2004; Jessop, 2008; Ahlqvist \& Moisio 2014) and scale theoretical literature (e.g. Smith, 1992; Marston, 2000; Brenner, 2001). We also assess how the increase of municipal autonomy in planning affects Finnish planning practitioners' abilities to bring broad and long-term concerns to the narrow municipal planning agenda (cf. Puustinen et al., 2017).

Hence, to unravel the increasingly market-reactive structures of planning, we discuss the problems that may emerge as a result of these ongoing changes related to administrative and legal structures. This issue has not yet been widely discussed by Finnish planning scholars. In similar vein, the international planning debate has also largely focused on the grass-roots level: on counter-measures to excessive use of power by the economically powerful in planning (Sager, 2013) and on the civil society movements that have organized against such market-driven pursuits in planning (e.g. Purcell, 2009; see also Purcell, 2016).

Some Finnish scholars have critically investigated the activities of local governments with respect to their pursuit of private investments (Rannila, 2018; Annanpalo, 2014; Nyman \& Mäntysalo, 2014). We suggest that increasing municipal power in planning - in the context of the unfolding legal reforms - leads to sub-optimized and market-conditioned planning. We argue that this tendency contributes to the neoliberalization of the entire planning regime, and, 
more precisely, to short-sighted reactiveness, especially in those municipalities which lack planning resources and/or which have exceptionally market-driven local planning cultures (e.g. Rannila, 2018). We ground our approach on the conclusions of several studies (Hytönen, Kotavaara \& Ahlqvist, 2018; Mäntysalo et al., 2010; Hytönen et al., 2012; Hytönen, 2016a) and evaluation projects (Association of Finnish Local and Regional Authorities et al., 2008; 2015; Ministry of Transport and Communications et al., 2009).

We have two main arguments in the paper. Firstly, we claim that this tendency in the Finnish planning regime results in the formation of so-called vacuums of strategic planning (cf. Hytönen, 2012; Hytönen et al., 2012). Vacuums of strategic planning are vacant spaces that are exploited by a variety of market actors who act on market-driven motivation: different business interests may take advantage of these uncoordinated spaces. The vacuums push strategic planning towards an institutionally unstable direction and limit manoeuvring room within public spatial planning. Especially the strategic framing of short-term projects realized through public steering in city-regional contexts becomes increasingly difficult (cf. Mäntysalo, Kangasoja \& Kanninen, 2015; Albrechts, 2010). In this situation, proactive land policies become increasingly reactive activities.

Secondly, we suggest that more effective steering instruments are required to counter the sub-optimization of land use and segregation of municipal economies that result from rising municipal planning autonomy in Finland. We base this argument on the results of empirical studies (Mäntysalo et al., 2010; Hytönen et al., 2012; Hytönen, 2016a) and an expert evaluation (Association of Finnish Local and Regional Authorities et al., 2015). Currently, many municipalities have insufficient resources for effectively coordinate land use planning (cf. Puustinen et al., 2013; Hytönen, Kotavaara \& Ahlqvist, 2018). In municipalities that have insufficient human resources, insufficient funding for land procurement, or that have strongly land-owner-led political culture, the planning apparatus is forced to apply reactive 
working methods that cause outcomes that are at odds with the long-term goals of planning. We argue that additional resources in, amongst others, master planning and in land procurement are needed to enable strategic land use planning that would be based on longterm goals set by democratic institutions, such as the national parliament through legislation and the municipal councils through steering of planning work.

The paper is structured as follows. The following section of the paper introduces the conceptual framework. The third section describes the recent legal reforms in land use legislation in Finland. The analysis focuses on the increase of municipal autonomy and its impacts on investment-seeking local planning practices and cross-municipal planning. In section four, we sketch an explorative scenario about potential long-term development. Finally, section five provides conclusions.

\section{Conceptual framework}

This section presents the conceptual framework of the paper. Firstly, we aim to build conceptual bridges between critical human geography and strategic planning theory (see e.g. Olesen, 2014; Allmendinger \& Haughton, 2013). Secondly, we scrutinize Finnish planning from the perspective of state transformation theory (e.g. Brenner, 2004).

\subsection{New state spaces and spatial planning}

An apt consideration of the changing regional planning is provided by the state transformation literature (e.g. Brenner, 2004; Jessop, 2008). This literature suggests that the regional structures of the state are coordinated by spatially and temporally conditioned economic imaginaries that are shared by selective fractions of the state elite. In the last few years, one such imaginary has focused on the emerging networks of city-regions (e.g. Scott, 2001; Ward \& Jonas, 2004; Rodríguez-Pose, 2008; Jonas \& Moisio, 2016). Accordingly, the re-shuffling of regional structures reflects a prevailing consensus amongst state elites, that is, it reflects the 
ideological views of 'global financiers' and 'investors' and the like. This re-shuffling process is realized in a constellation formed by states and international organizations, such as the EU and OECD (Jonas \& Moisio, 2016). According to this view, the role of the public institutions - such as the municipal planning apparatus - is to support 'investment consortia's' promotion of 'territorial imaginaries as part of ongoing efforts to position their host city regions more favourably in relation to wider circuits of state social and physical investment' (Jonas \& Moisio, 2016, p. 14).

Furthermore, it has also been suggested that states are hollowing out. The notion of a hollowing state (Rhodes 1994) refers to the withdrawal of the state from certain public activities and to the concomitant fettering of the use and distribution of public power (cf. letdo neoliberalism; Purcell, 2009; Olesen, 2014). However, Goodwin, Jones and Jones (2005) have proposed that the notion provides a mistaken perspective to the discussion on state restructuration. They argue that even though certain elements of the state are being hollowed out on some scales, there are other elements and scales on which the state's role is actually getting stronger and 'filling in'.

Brenner (2004) has argued that the present state transformation is occuring through 'new state spaces', that is, new spatial units through which the state transforms its mode of governance towards plural and market-oriented forms. In the Finnish context, the formation of 'new state spaces' can be seen in the ongoing regional government reform in which state power is planned to be channelled and re-allocated to the Finnish regions, especially with respect to social and health care. This ongoing reform can be considered a national-scale vision that aims at harmonious administration and efficient service provision. However, the realization of such national visions is always complex. Frictions emerge when visions are taken to the implementation stage and merge with the regional and municipal realities, which are never fully grasped by the national plans. Regarding land use planning in Finland, 
contradictory features exist in the present legislative framework, for example, elements promoting long-term sustainability and elements promoting short-term growth. We suggest that the 'imperfect' nature of the rescaling reforms opens up more room for such contradictions.

Eventually, the transformation will result not only in a reorganization of state power. It will also lead to a tightening of room for public regulative manoeuvring in land use planning by state authorities. This diminishing room is only partly compensated for through the strengthening of the discretionary powers of the municipal authorities. In this situation, market forces will set the terms of the democratic steering of planning more than before. This is because, firstly, the devolution of regulation to municipalities increases municipal competition and market-reactivity in land use planning and, secondly, the long-term sustainability-enhancing regulative framework (presently provided by the state) will fade into background and erode.

In such an operational environment, in line with Brenner's (2004) argumentation about market-oriented forms of state transformation, the role of planning will be more about facilitation of narrow private initiatives in the short term than about long-term practices for ensuring sustainability (cf. Mattila, 2017; Hrelja, Isaksson \& Richardsson, 2012). This arrangement will weaken planners' proactive role and strong authority to bring 'broader concerns' to the planning agenda (see Hytönen, 2016b). Hence, collective notions about public interest will yield to more individualistic ones (Hytönen, 2016b; Puustinen et al., 2017; Puustinen, Mäntysalo \& Jarenko, 2017). We thus argue that with respect to securing the longterm sustainability goals in land use planning, the state can be a progressive force that provides regulation stability and insulation from the most drastic market volatilities.

Activities at the municipal scale are complex mixtures of state governance and localized political practices. Private capital seeks investment opportunities in local contexts 
and thus creates 'local investment envelopes' that are partly outside the scope of state and regional regulation. In Finland, an apt example is the planning of commercial shopping centres, which are built based on unique local choices. These decisions result in a fluctuating landscape of market locations that is difficult to reconcile with the long-term state planning aims. Thus in this respect, the local planning agenda in Finland is, to a considerable extent, market-reactive (Hytönen, 2016a; Nyman \& Mäntysalo, 2014; see also Hrelja, Isaksson \& Richardsson, 2012). Market actors thus benefit from the randomness and short-sightedness of local city-regional planning. Hence, increasing the strategic capacities of regions in land use planning is important for fostering a more long-term planning culture.

\subsection{Market-reactivity and neoliberalization of strategic spatial planning}

By strategic planning we refer to a practice in which short-term project-based land use development is set in a long-term framework (see Mäntysalo, Kangasoja \& Kanninen, 2015). Following Albrechts (2010), long-term frameworks can be realized through processes of envisioning in which the planner broadens the conventional perspectives of the stakeholders. This approach encourages seeking of alternative futures for land use, and differs from traditional comprehensive planning (see also Albrechts \& Balducci, 2013).

Understanding long-term frameworks is premised on a critical reading of traditional comprehensive planning: traditional comprehensive planning is seen to be based on rigid and technical rationalist thinking, whereas strategic planning is seen to have its basis in a collective and creative vision. In strategic planning theory, the pursuit of comprehensiveness has thus shifted towards the pursuit of strategic selectivity (Healey, 2006). In Albrechts' (2012) view, citizens are brought into the process of strategic planning through practices of coproduction and community involvement, thus increasing the legitimacy of planning.

Whereas Albrechts' focus is largely on the global south (regarding Albrechts, 2012), Mäntysalo, Kangasoja and Kanninen (2015) examine strategic planning primarily in the 
Finnish regulatory context. They conceive of it as 'strategic wisdom', as a continuous programming of detailed, statutory planning processes. Thus, strategic planning is not about filling the gaps of rigid statutory planning or about constructing strategic plans outside the statutory planning system. Instead, strategic planning is about managing the use of the entire hierarchic planning system. The approach suggested by Mäntysalo, Kangasoja and Kanninen has some similarities to the approaches developed, for example, by Albrechts $(2010 ; 2012)$ and Albrechts and Balducci (2013). The differing factor is the issue that Mäntysalo et al. do not withdraw from the statutory planning hierarchy but instead build on it. They point a way towards strategically wise planning by making use of the existing planning context and underline the need for sufficient attachment to the institutional regulatory setting in support of unconventional strategic planning.

However, the statutory planning system in Finland is currently transforming towards a market-driven, market-reactive and short-term direction. This direction is clearly visible in a study we conducted among Finnish land use planners working in municipalities of different size (Hytönen, Kotavaara \& Ahlqvist, 2018). According to our empirical study, this situation is an outcome of three parallel development trajectories: 1) changes in the state-scale land use regulation and legislation; 2) fragmentation and competition between neighbouring municipalities in land use decisions; and 3) lack of adequate planning resources and capabilities on the municipal scale.

We interpret the resulting situation as the ideologically driven attempt to deflate politically steered regulative capacity in strategic planning, and as an attempt to 'liberate' public regulation in favour of market forces (see Gunder, 2010). Such a tendency may emerge, for example, as a short-sighted and reactive working culture in the municipalities, catalyzed by a lack of sufficient planning resources, as was indicated in our study (Hytönen, 
Kotavaara \& Ahlqvist, 2018; see also Puustinen et al., 2013). In addition, landowner-centred planning policies are pivotal in our understanding of market-reactive planning.

In the context of strategic planning, growth-oriented and competitiveness-driven agenda setting is perhaps the main driver of such (help-do) neoliberalization (see e.g. Olesen, 2014). However, the neoliberalization of strategic planning is often realized through unregulated spaces of planning that become unravelled through the dynamics of the multiscalar planning process. These 'blank spaces' can form in multiple ways: sometimes intentionally through straightforward deregulation (let-do neoliberalism, Olesen, 2014) and sometimes unintentionally through the complex interplay of local decision-making.

We argue here that increasing short-termism and market-reactivity, combined with the lack of adequate planning resources, erodes the institutional capacities for strategically wise planning in Finland. To conceptualize this erosion, we present the notion of 'vacuum of strategic planning' in the next section.

\subsection{Formation of vacuums of strategic planning}

The concept of vacuum was initially developed in a text that discussed the poorly recognized spaces in proactive public land use planning that may result from excessive municipal orientation in Finnish regional planning (Hytönen, 2012; in Finnish strateginen tavoitetyhjiö, 'vacuum of strategic objectives'). This approach was motivated by negative findings about inter-municipal cooperation in Finnish land use issues (Mäntysalo et al., 2010; Hytönen et al., 2012). In the present paper, we aim to elaborate the concept further. As noted, the formation of vacuums is connected to the increase of short-termism and market-reactivity in spatial planning (see e.g. Mäntysalo, 1999).

A vacuum can be defined as a rapidly emerging vacant or underutilized operational space that becomes unravelled through sub-optimizing strategic planning practices. Strategic 
planning practices can facilitate the emergence of vacuums in several ways. Firstly, strategic planning may, intentionally or unintentionally, cause certain types of activities to become unregulated, or only lightly regulated. Local market actors can then exploit these 'blank' spaces. Secondly, strategic planning may conflate or neglect the disparate strategic roles of public and market actors. This opens manoeuvring room for swift market actors. Thirdly, strategic planning may endow market actors with specific liberties. This is the most direct way to expand the vacuums and to increase poorly coordinated facilitation of business opportunities.

The notion of vacuums of strategic planning can be compared to that of 'institutional void'suggested by Hajer (2003). Hajer uses the concept to describe the discrepancy between traditional forms of policy-making and the complex problems they have to deal with, and how the discrepancy should be addressed within policy analysis. He points out that classic institutions 'lack the authority or focus needed for problem solving that is widely perceived to be both effective and legitimate' (Hajer, 2003, p. 177). Partly departing from Hajer's focus, we wish to shed light on a new kind of planning practice and related actor assemblage that fosters short-term market-reactive planning on the local scale.

Vacuums have three intertwined dimensions (see Figure 1):

1. Horizontal dimension - The vacuum emerges as an outcome of inter-municipal rivalry, like in the context of city-regions. The vacuum is a result of the horizontal composition of planning in which no public organ, or scale of government, is responsible for planning that crosses municipal borders. This dimension draws attention to the friction between planning policies of different municipalities. Here we discuss the horizontal dimension in the context of Finnish city-regional planning (see section 3.3). 
2. Vertical dimension - The idea here is to draw attention to the dysfunctionalities of the supposedly hierarchic land use planning system. From a vertical perspective, the vacuum emerges from the incoherence or mutual mismatch of legally binding zoning tools at different spatial scales. For example, in the absence of legally binding cityregional planning tools, the municipal plans currently provide the only operational planning tools, as noted in the evaluation of the Finnish Land Use and Building Act (Ministry of Environment, 2014). Eventually, local market actors are able to exploit the local 'rules of the game' through local actor networks, heedless of the wider, or more long-term, consequences of their activities. Administrative reforms may deepen these incoherencies by increasing the municipalities' power in relation to the central government. We discuss the vertical dimension in the context of relegation of planning powers in Finland (see section 3.1), and in the context of the emerging regional model (see section 4).

3. Pervasive dimension - This dimension derives from the strong growth-orientation dynamics of local planning, as in the case of the strong influence of landowners in municipal politics (Rannila, 2018; Mäntysalo et al., 2010; Hytönen et al., 2012). Like the vertical dimension, the pervasive dimension is connected to the antagonism between the planning scales. However, the pervasive dimension emphasizes municipalities' increasingly market-driven land use practices, especially (but not exclusively) in small municipalities characterized by inadequate planning resources (Puustinen et al., 2013) and by strong managerial pressures exerted on planning practitioners (Hytönen, Kotavaara \& Ahlqvist, 2018). Municipal actors may deem external influence, such as state-scale steering, patronizing and overly bureaucratic (Kanninen \& Ylä-Anttila, 2011; Hytönen et al., 2016). We discuss the pervasive dimension in the case study of South Karelia (see section 3.2). 


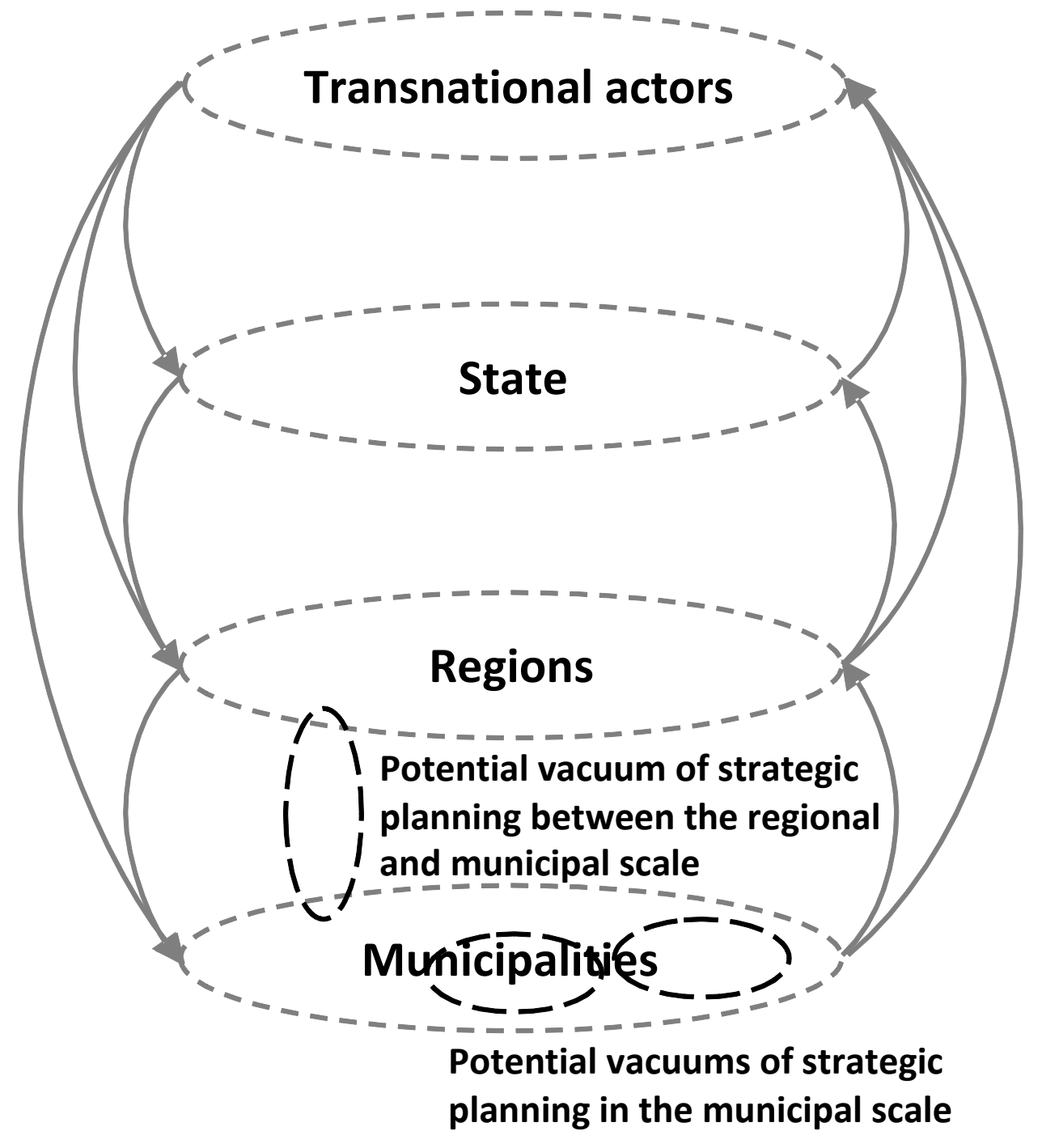

We argue that the formation of vacuums could be controlled by an institutionally robust strategic planning system that builds on democratic practices and on relatively stable statutory anchors, insulating local planning from excessive market-oriented behaviour. In the rest of the paper, we scrutinize how, and through which kinds of municipal planning practices, strategic vacuums form in, and between, the local and regional scale. 


\section{Impacts of changing governance of spatial planning in Finland}

To date, an interplay of the state authorities and the municipalities has characterized the planning system of Finland. Direct elections, organized at the national and at the municipal level only, have buttressed the institutional strength of the two scales, which have strong discretionary powers. As noted, the regional planning tier lacks such institutional support from direct elections. In this section, we analyze how the changes in Finnish legislation, particularly in the Land Use and Building Act (Government Bill 114/2015; Government Bill 251/2016), may modify these relationships between the scales of government. We argue that the withdrawal of state supervision in spatial planning will catalyze vacuums of strategic planning.

\subsection{Relegation of power in the Finnish spatial planning system}

Despite the strong autonomy of municipalities in Finland, the state central government including the Ministry of Environment and the state's regional Centres for Economic Development, Transport and the Environment (CEDTE Centres) - has had a relatively strong guiding role in certain parts of the land use planning system. According to the government policy at present, the goal of the Finnish government is to decrease the state's oversight and binding role towards municipalities (Prime Minister's Office, 2015).

The first changes to land use legislation were introduced in 2015. At the time, the conservative government, led by the Centre Party, reduced the role of the state in regional planning (Government Bill 114/2015). Following a similar decision concerning municipal planning some 15 years earlier, the result of the actions in 2015 was that regional plans no longer have to be ratified by the state ministry. With respect to most issues, the regional plans have traditionally had more of a facilitative and endorsing character: the regional plans have not held significant steering power in the municipalities. This is because the planning processes have been steered by municipal representatives rather than a directly elected council 
(see Ministry of Environment, 2014). In the present situation, regional councils draft and ratify the regional plans in direct steering by the municipalities.

This is a significant change, because with respect to some issues, such as the location of large-scale retail centres, the earlier regional plans had an independent steering role manifested through ratification by the Ministry of Environment. Hence, currently, the ministry is no longer able to affect the planning of out-of-town retail locations in urban regions to the same extent as before (see section 3.2).

In 2016, the government introduced another initiative to change the legal framework of spatial planning. These changes, implemented in 2017, further eroded the role of state authorities. The state authorities, the regional CEDTE Centres, no longer hold a guiding role in local land use planning. The CEDTE Centres' right to appeal to administrative courts is now limited to those municipal planning decisions that have wider regional or national impacts. The central government's possibilities to make legal appeals on local land use issues are strictly being limited. ${ }^{2}$ In the case of planning that has presumably merely local impacts, the municipality no longer needs to consult the state authorities during the planning process (Government Bill 251/2016).

The legal changes also include elements that directly restrict the regulative capacity of the municipalities in relation to market actors. One such example is the weakening of the tools through which loggings on landscape-sensitive areas can be controlled via local planning. Another instance concerns the detailed legislation on retail planning. For example, larger retail actors can now more easily seek out-of-centre locations, without the need to meet special criteria concerning the location of large-scale units. The limit of what is considered a large-scale unit has risen from 2000 to $4000 \mathrm{~m}^{2}$ according to the new legislation (Government Bill 251/2016). The steering capacity is not only moving from the state scale to the local scale, but it is simultaneously made more market-reactive by allowing market actors 
to engage in local planning in novel ways. This development not only narrows the democratic regulation of planning on both the state and local scales, but also augurs an unprecedented shift in the Finnish spatial planning system.

The recent changes in the Land Use and Building Act may be considered an indirect deflation of public steering capacity over market actors. Even though the municipalities will still hold steering power in the case of retail locations, the municipal planning practitioners' capacity to keep sustainability-related issues, such as private car independency, on the planning agenda will likely weaken (cf. Hytönen, Kotavaara \& Ahlqvist, 2018; Hytönen, 2016a). As mentioned, the regulative capacity of the state in relation to the regulative capacity of the municipalities will change, too. The result may be that the formation of vacuums of strategic planning will intensify due to the so-called defensive routines through which municipalities safeguard their planning autonomy against external pressures (Hytönen et al., 2016).

Thus, the relegation of power from the state scale to the local scale could induce vacuums of strategic planning in three ways: relegation of planning power changes the workings of the planning system (vertical dimension), which increases short-sighted local planning practices (pervasive dimension). This will result in a narrow municipal focus that is sub-optimal as regards city-regional planning (horizontal dimension).

In the following sections, we present case studies that illustrate empirically the different vacuum dimensions. The cases reveal how the long-term planning agenda, geared towards sustainability, is hampered by the emerging planning practices and how planning practitioners are forced to accommodate the priorities set by regional and local managers.

\subsection{Vacuum in a local scale: the case of South Karelia}

Our first empirical case is a study concerning regional planning and hypermarket steering 
(Hytönen, 2016a). ${ }^{3}$ The case focuses on regional planning steered by municipalities that are more or less dependent on market actors and private investments. The case is an illustrative example of a struggle over discretionary powers of spatial planning between the state scale and the local scale. The case also highlights how differently sustainability aims in land use legislation can be interpreted in local and state scales. ${ }^{4}$

South Karelia is a region in southeast Finland. It is located next to the Russian border, midway between Helsinki and St Petersburg. Because of its location, the South Karelian region has become a popular shopping destination for Russian tourists. The increase of Russian visitors has been a challenge for regional land use planning.

In the early 2000s, partly because there was pressure to increase the number of largescale retail locations in the region, the regional council of South Karelia decided to draft a new regional plan. The process started in 2004. At the time, regional plans still had to be submitted to the Ministry of Environment for ratification. The regional plan of South Karelia was submitted to the ministry in 2010. Ultimately, the ministry decided not to ratify three major out-of-town retail locations presented in the plan.

This decision caused a major conflict between the Ministry of Environment and the municipal and regional actors. Local sentiment came to view the ministry as an inconsistent and authoritarian regulator with no intention of supporting the regional council (Hytönen 2016a, pp. 50-51). Thus, the local actors interpreted that the state government was unnecessarily violating municipal autonomy in land use planning.

Hytönen's (2016a) analysis shows the tendentiousness of this local discourse. Contrary to the local argumentation, the plan proposed by the regional actors was not based on the findings of impact assessments, or on any valid estimations of potential Russian visitors. Actually, the intention of the regional plan was to set no quantitative restrictions that could limit the planning of the potential retail areas, and to avoid any steering of the 
municipal masterplans. Later on, the unsustainability of the three hypermarket locations was rather unquestionably evidenced in the ministry's ratification report.

The state restricted the South Karelian regional plan initiative on the grounds of longterm unsustainability. The reasoning was that the regional plan would have excessively dispersed the community structure of the city region, and therefore increased car-dependency. Thus, the case shows that without the state-scale tools for supervising regional and local planning decisions, the South Karelian regional plan would have proceeded on a purely market-driven basis, even though it was in conflict with the general goals of the Land Use and Building Act. The case indicates that the regional management of South Karelia, along with local political actors, strongly pushed for a facilitative planning solution. In this case, the consideration of the potential long-term consequences of planning solution was 'outsourced' to the state scale. Without assessment and adjustment by the state, the regional plan would not have met the general sustainability-related goals of legislation.

Using the terminology presented in this paper, the South Karelian regional plan aimed at exploiting a vacuum created in the interplay between private actors seeking retail locations and the regional management seeking private investments. Motivated, perhaps, by unemployment and the flagging municipal economy, some regional actors sought loopholes in the state regulation in order to attract market actors through facilitative practices. The regional planning practices expressed a pervasive and reactive growth-orientation, typical of Finnish municipal administration. Thus, regional actors firstly ignored and then deemed patronizing the restrictions set by the central government. Therefore, the case manifested two vacuum dimensions: short-sightedness in local planning practice (pervasive dimension) and regarding the relegation of planning powers from the central government to the municipalities - dysfunctionalities of the planning system (vertical dimension). In the next section, we discuss the vacuums of strategic planning in a city-regional context. 


\subsection{Emerging city-regionalism: cross-municipal planning problematic}

As a second case, we discuss the emerging city-regionalism in Finland. From the perspective of city-regions, certain features of the Finnish land use planning system can be considered problematic: these include various aspects of inter-municipal competition and its consequences regarding land use. The problems are connected to strong municipal autonomy and the lack of city-regional planning tools operating beyond the municipal level. The mismatch between municipal planning perspectives and the city-regional planning perspectives are a familiar problematic in several countries. Nonetheless, in Finland this problem is acute as the municipalities hold a relatively strong planning autonomy compared to other countries (Prusi, 2013).

The central government and the Association of Finnish Local and Regional Administrations, which is a central cooperation organisation and a lobby for the municipalities in the country, have recognized the above-mentioned challenges. Together with four Finnish ministries, the Association conducted an expert evaluation of cross-municipal cooperation in 11 Finnish urban regions in 2015 (Association of Finnish Local and Regional Authorities et al., 2015). ${ }^{5}$ The evaluation covered planning issues in land use, housing and transport. The metropolitan region of Helsinki was not included in the evaluation. According to the findings, inter-municipal cooperation in urban regions has been continuously weakening (Association of Finnish Local and Regional Authorities et al., 2008; Ministry of Transport and Communications et al., 2009). The results of the evaluation can be summarized as follows:

- The control of community structures, e.g. tools to control dispersed housing and land politics, is the weakest form of municipal cooperation in the urban regions. There are deficiencies especially in the implementation of strategic, informal plans as well as in cooperation on land procurement and plot policy. 
- The commitment to cross-municipal cooperation, especially in terms of resourcing and tracking of cooperation, was considered 'irregular'. While some municipalities were committed to cooperation, in general cooperation was viewed rather pessimistically.

- In cross-sectoral issues, such as land use, housing and transport planning, regional cooperation was at a relatively good level compared to other issues.

There are only two Finnish urban regions - Tampere and Oulu - in which the cooperation was considered relatively successful. In both of these cases, the state has been actively involved as a stakeholder through regional arrangements called 'Agreements Concerning Land Use, Housing and Transport'. In these arrangements, municipalities arbitrate with the state authorities on goals concerning, for example, social housing issues and large public transport investments. Still, taken as a whole, the Finnish municipalities have not adopted city-regional planning practices to a significant extent. The political discussion on the core issues concerning effective inter-municipal planning cooperation has often been avoided despite the state's efforts to encourage municipal cooperation (Hytönen et al., 2016). In addition, the adopted tools of inter-municipal planning have lacked concrete steering power. Strategic utilization of soft and informal instruments of cross-municipal planning in tandem with statutory planning tools has proven difficult thus far. Creating effective city-regional planning would require not only understanding of the interconnections between strategic planning and the statutory planning system, as Mäntysalo, Kangasoja and Kanninen (2015) suggest, but also institutional stability and a strong legitimacy basis.

The expert evaluation (Association of Finnish Local and Regional Authorities et al., 2015) describes how land use planning is tightly in the hands of the municipalities and how the municipalities have not been willing to engage in tighter cooperation. Only the two abovementioned city-regions, in which the state has taken an active role to foster cooperation, are an exception to this rule, and these only to a certain extent. This indicates that there are 
inhibiting structures in the land use planning system that cannot be tackled via voluntary inter-municipal cooperation. Municipalities within the city-regions compete with each other for tax income and work places. Studies have also shown that socio-economic segregation has continued between municipalities. Those municipalities with favourable locations are able to capitalize on the situation, for example, by offering housing possibilities for affluent citizens (Mäntysalo et al., 2012; Hytönen, 2016a).

We assess that this unbalanced situation between strong municipal planning autonomy and weak city-regional planning tools, particularly the lack of coordination mechanisms, creates a high potential for the formation of vacuums of strategic planning. This is because the current land use planning system for urban regions is organized in such a way that it fosters sub-optimization and competition between municipalities. Vacuums may form, for example, when municipalities are planning, and competing for, industrial sites or private retail locations. This could result in a situation in which municipalities in the same city-region host large private retail locations close to each other, separated just by the municipal border. In the long term, this type of development leads to sub-optimal planning and ineffective urban structures, as the locations of retail and housing units, or industrial sites, are chosen solely on municipal priorities. This, in turn, could result in counterproductive results, such as increases of private car traffic. In our understanding, sub-city regional sub-optimization is a problematic and lead to an uneven playing field regarding organization of democratic steering of land use.

What are the future prospects of city-regional planning? There are good reasons to expect that city-regional planning will strengthen, in a one way or another. As the role of the central government is already diminishing, it is hard to imagine that the state would take a strong role in directing city-regional planning in the future. Instead, city-regional planning is likely to be realized through cross-municipal planning cooperation. In this setting, the role of the 18 Finnish regions is an open question - Could regions be key actors in city-regional 
planning? So far, the steering power of the regional plans has been low in relation to the municipal plans (Ministry of Environment, 2014). Only one thing seems certain: the marketreactive tendency is likely to increase. This tendency is manifested, for instance, in a recent Ministry of Environment report on the renewal of the land use legislation: the report suggests that the detailed planning would be partly farmed out to private developers and landowners (Ekroos et al. 2018).

\section{The 'vitality task' and potential regional models: towards new scalar friction?}

In this section, we discuss possible futures of strategic planning in the context of redefinition of the municipalities' tasks and the regional model, which will possibly emerge in Finland.

For years, there has been strong political pressure to reorganize social and health care service provision in the country, and, because of this pressure, a regional model is likely to emerge in Finland during the coming years. At the moment (January 2019), an administrative tier of 18 regions with directly elected councils is being prepared by the government. ${ }^{6}$ The municipalities would be responsible for land use planning, but organizing social and health care services would become the task of the regions. Further, even though the specific form of the regional model and its timetable are still uncertain, planning has already been receiving increasing interest in the discussions about the main tasks of the municipalities. The municipal decision makers' present focus on organizing social and health care would be replaced with land use planning as part of the so-called 'vitality task'.

The 'vitality task', elinvoimatehtävä (e.g. Ministry of Finance, 2017), is a peculiar combination of long-term sustainability priorities and a short-term economic priorities, and may potentially lead to increasingly market-reactive planning practices. In general, enhancing local vitality as a new emphasis among municipalities' tasks has been promoted for several years (about different definitions of vitality, see Hytönen, Kotavaara \& Ahlqvist, 2018, pp. 5- 
6). Such discourse has emerged partly independently of the debates about the preparation of the new regional model.

In the following list, we summarize our expectations regarding the future of Finnish land use planning. The impacts of the 'vitality task' are taken into consideration in the listing, together with the potential impacts of the emerging regional model. If the regional model emerges in the planned or in a similar form, the abolished municipal responsibilities regarding social and health care will be compensated, we argue, by the 'vitality task', including its emphasis on land use planning (cf. Ministry of Finance, 2017, p. 13). However, the list is primarily based on our conception of the recent and forthcoming changes in the planning legislation, and of the increased power of the local municipal scale in relation to the state government.

- In land use planning, the direct regulative capacity of the state scale will diminish. The state's regional CEDTE Centres are abolished and the Ministry of Environment ceases to have a significant role in land use issues.

- The municipalities will act under detailed legislation that is more market-oriented than before.

- Those municipal planning practitioners who still have a commitment to long-term and sustainable planning will face pressures to facilitate growth in the short-term.

- The possibly emerging regions will not have a significant role in land use planning in the first instance.

- Land policies, including public land acquisition, will remain a municipal task. Accordingly, the viability of strategic planning will continue to be conditioned by municipal decision-making. The control of housing sprawl will potentially loosen due to the state's limited rights to appeal. 
The municipal 'power excess' in land use planning creates potential for the formation of vacuums of strategic planning. The horizontal friction between the municipalities will thus catalyze the formation of horizontal vacuums, despite the development of voluntary agreements and other soft instruments used in some Finnish urban regions. The weakening of the hierarchic land use planning system is likely to open vertical vacuums and increase landowner-based and market-reactive pressures. Hence, the horizontal friction between municipalities and the vertical disintegration of the planning system could also induce the pervasive dimension of vacuums by opening up 'blank spaces' and zones of light regulation for market actors. In these vacuums, market actors could temporarily gain powers that overtake democratically steered authorities.

\section{Conclusions}

In the paper, we have explored the emerging changes in the Finnish spatial planning system. We have elaborated the conclusions of several empirical studies (see previous sections) that have indicated different gaps in the current planning system. These gaps include lack of cooperation in urban regions and insufficiency of planning resources in small municipalities. Recent studies also point to excessive market-reactivity in municipal planning. We have argued that the systemic interaction of these tendencies could escalate in different ways, especially if the capacity of municipal public planning to intervene in market activities is further eroded. These are pivotal changes from the point of view of strategic planning and its institutional framework, especially in a Finnish administrative context that is expected to face a major renewal in the coming years.

It remains to be seen what the consequences of adoption of the so-called vitality task in the municipalities will be. It could foster new perspectives and help in building better understanding of long-term planning issues. However, the risks should be noted, too. This 
new task may advance an increasingly instrumental and facilitative understanding of land use planning. Because of the parallel development of relegation of steering power from the state scale to the local scale and reduction of steering power of municipalities in relation to market actors, the possibilities for continuous programming of statutory planning - or visionary selectiveness - may narrow. In other words, the ongoing processes in the Finnish spatial planning system hold the potential to reduce the 'planning space' in which alternative futures can be outlined in an institutionally firm and legitimate manner. As our empirical study (e.g. Hytönen, Kotavaara \& Ahlqvist, 2018) indicates, also the current resources for insightful visionary work are often insufficient.

Hence, Finnish planning culture may be actually moving in a less publicly regulated and increasingly market-reactive direction (cf. Olesen, 2014). If the planning regime becomes oriented towards short-term and technically narrow concerns, the more long-term anticipation of wider planning concerns will become increasingly difficult. We suggest that this may create unintended spaces for 'pragmatic' profit-seeking motives in local planning. There is a risk that the planning practitioners will face difficulties in addressing topics that are beyond this pressing 'market-reactive pragmatism'. Because of the differences between Anglophone common law-based legal culture and the Nordic parliament-based legal culture, the courts cannot function in Finland as guarantors of 'fair' or sustainable planning in the same way as in most Anglophone countries (Hytönen, 2016b). This is why seemingly minor pro-market changes in legislation could end up causing relatively drastic shifts in the entire planning culture.

We argue that the market-reactivity of spatial planning may increase due to the rescaling of state power to the regional scale, but also because of the new municipality emphasis on local spatial planning in Finland. Here we have complemented the perspective of Jonas and Moisio (2016). We have conceptualized these tendencies through the concept of 
vacuums of strategic planning, a concept that bridges aspects of critical strategic planning theory and human geography.

In order to manage the formation of vacuums, there is a need for stronger steering mechanisms targeted at the city-regional scale. The mechanisms should be sensitive to the local orientation of land use planning, and take into account the variegated local contexts and coalitions. Contextually sensitive steering mechanisms would endorse sustainable and longterm strategic spatial planning, and enable the fine-tuning of local market-based developments. To reach these aims requires a strengthening of representative democratic control of regional policies as well as a bolstering of planning resources for smaller municipalities.

We suggest that a more contextualized planning theory is also required, one that takes into account the impacts of societal and national contexts. Our approach springs from a Nordic context, characterized by high trust in state institutions and high acceptance of public spending. Hence, our thinking diverges from the most sceptic conceptions about the state and state regulation. For example, Purcell (2016) argues that the state blocks the development of a more democratic society as it prevents people from managing their own affairs. Contrary to this perspective, the state could also be perceived as a progressive force that prevents excessive market-reactivity by regulating the vacuums of strategic planning and by enabling long-term sustainable planning practices. If regulated in an adequate fashion, the vacuums of spatial planning could, perhaps, provide possibilities for the emergence of new democratic practices, supporting individuals and collectives that wish to manage their own affairs. However, it is presently hard to find evidence of this sort of 're-democratization through strategic vacuums'. As we illustrated in the paper, currently the expanding vacuums tend instead to reduce the rule of law and democracy in planning, and serve the profit-seeking motives of 'global investment consortia'. 


\section{Declaration of interests}

No potential conflict of interest was reported by the authors.

\section{References}

Ahlqvist, T. \& Moisio, S. (2014) Neoliberalisation in a Nordic State: From Cartel Polity towards a Corporate Polity in Finland. New Political Economy 19(1), 21-55.

Albrechts, L. (2010) Enhancing Creativity and Action Orientation in Planning. In: Hillier J \& Healey P (eds.) The Ashgate Research Companion to Planning Theory. (pp. 215-232.) Farnham: Ashgate.

Albrechts, L. (2012) Reframing strategic spatial planning by using a coproduction perspective. Planning Theory 12(1), 46-63.

Albrechts, L. \& Balducci, A. (2013) Practicing Strategic Planning: In Search of Critical Features to Explain the Strategic Character of Plans. dis $P$ - The Planning Review 49(3), 16-27.

Allmendinger, P. \& Haughton, G. (2013) The Evolution and Trajectories of English Spatial Governance: 'Neoliberal' Episodes in Planning. Planning, Practice \& Research 28(1), 6-26.

Annanpalo, H. (2014). Toteutuuko kuntalaisen oikeus osallistua kaavoitukseen? [Does citizens' right for participation in planning come true?] Yhdyskuntasuunnittelu, 45(2), $53-69$.

Association of Finnish Local and Regional Authorities, Ministry of Transport and Communications, Ministry of Employment and the Economy, Ministry of Finance \& Ministry of Environment (2015). Maankäyttö, asuminen ja liikenne: Kaupunkiseutujen yhteistyön tilan arviointi 2015. Retrieved from:

http://shop.kunnat.net/download.php?filename=uploads/kaupunkiseutujenyhteistyo_eb ook.pdf

Association of Finnish Local and Regional Authorities, Ministry of Transport and Communications, Ministry of Education, Ministry of Social Affairs and Health, Ministry of Employment and the Economy, Ministry of Finance \& Ministry of Environment (2008). Kaupunkiseutusuunnitelmien asiantuntija-arvioinnin loppuraportti. Helsinki: Miktor Oy. 
Brenner, N. (2001). The limits to scale? Methodological reflections on scalar structuration. Progress in Human Geography 25(4), 591-614.

Brenner, N. (2004). New state spaces. Urban governance and the rescaling of statehood. Oxford University Press, Oxford.

Ekroos, A., Katajamäki, H., Kinnunen, H., Lehtovuori, P. \& Staffans, A. (2018) Maankäytön ja rakentamisen ohjauksen uudistaminen. Ympäristöministeriön raportteja 7/2018. Helsinki: Ministry of Environment.

Goodwin, M., Jones, M. \& Jones, R. (2005) Devolution, constitutional change and economic development: Explaining and understanding the new institutional geographies of the British state. Regional Studies 38(4), 421-436.

Government bill 114/2015. Government bill on amendment in Land Use and Building Act.

Government bill 251/2016. Government bill on amendment in Land Use and Building Act.

Gunder, M. (2010) Planning as the ideology of (neoliberal) space. Planning Theory 9(4): 298-314.

Hajer, M. (2003) Policy without polity? Policy analysis and the institutional void. Policy Sciences 36, 175-195.

Healey, P. (2006) Relational complexity and the imaginative power of strategic spatial planning. European Planning Studies 14(4), 525-546.

Hrelja, R., Isaksson, K. \& Richardsson, T. (2012). IKEA and small city development in Sweden: Planning myths, realities, and unsustainable mobilities. International Planning Studies 17(2): 125-145.

Hytönen, J. (2012) Kaupunkiseutujen hajautumisen suunnittelematon luonne. In: Hirvonen, T. \& Kotavaara, O. (eds.) ESPON tekee tulosta. Nordia Tiedonantoja 1/2012, 115-129. Retrieved from: www.espon.fi/Kuvat/ESPON\%20tekee\%20tulosta.pdf

Hytönen, J. (2016a) Kuntien ja valtion välinen vastuiden ja vallan jako yhdyskuntapolitiikassa. Online publication of Association of Finnish Local and Regional Authorities. Retrieved from: http://shop.kunnat.net/download.php?filename=uploads/1781yhdyskuntapol_vastuutja valta_ebook.pdf

Hytönen, J. (2016b) The problematic relationship of communicative planning and the Finnish legal culture. Planning Theory 15(3), 223-238.

Hytönen, J., Kotavaara, N., \& Ahlqvist, T. (2018) Elinvoiman askelmerkkejä ja ristiriitoja. Maankäytön suunnittelijoiden näkemyksiä kuntien tulevaisuuteen. ARTTU2- 
tutkimusohjelman julkaisusarja 5/2018. Association of Finnish Local and Regional Authorities. Retrieved from http://shop.kunnat.net/download.php?filename=uploads/arttunro5_2018.pdf

Hytönen, J., Mäntysalo, R., Akkila, I., Kanninen, V. \& Niemi, P. (eds.) (2012) Kaupunkiseutujen kasvukivut II. Päätelmiä maankäytön suunnitteluyhteistyön kehityksestä viidellä kaupunkiseudulla. Evaluation Research Programme ARTTU Studies 22. Acta Publications 241. Helsinki: Aalto University and the Association of Finnish Local and Regional Authorities. Retrieved from http://shop.kunnat.net/uploads/acta241_kasvukivutebook.pdf

Hytönen, J., Mäntysalo, R., Peltonen, L., Kanninen, V., Niemi, P., \& Simanainen, M. (2016) Defensive routines in land use policy steering in Finnish urban regions. European Urban and Regional Studies 23(1), 40-55.

Jessop, B. (2008). State power. Polity Press, Cambridge.

Jonas, A. \& Moisio, S. (2016) City regionalism as geopolitical processes: A new framework for analysis. Progress in Human Geography. Online publication ahead of print 25.11.2016. doi: 10.1177/0309132516679897

Kanninen, V. \& Ylä-Anttila, K. (eds.) (2011) Monikeskuksisuuden monet todellisuudet. Sektoritutkimuksen neuvottelukunta 4/2011. Aalto University \& Tampere University of Technology.

Mattila, H. (2017) Revisiting Habermas. Exploring the Theoretical Roots and Contemporary Challenges of Communicative Urban and Regional Planning (Doctoral dissertation). Aalto University publication series. Doctoral dissertations 91/2017.

Mattila, H. \& Hytönen, J. (2016) Lost in translation? Yhdyskuntasuunnittelu 54(2), 113-115.

Marston, S.A. (2000). The social construction of scale. Progress in Human Geography 24(2), 219-242.

Metzger, J., Allmendinger, P. \& Oosterlynck, S. (2015) The contested terrain of European territorial governance. In: Metzger, J., Allmendinger, P. \& Oosterlynck, S. (eds.) Planning Against the Political: Democratic Deficits in European Territorial Governance. (pp. 1-27). New York: Routledge.

Ministry of Environment (2014) Arviointi maankäyttö-ja rakennuslain toimivuudesta 2013. Finnish Environment 1/2014. 
Ministry of Finance (2017) Tulevaisuuden kunta - asiantuntijaryhmän muistio sote- ja maakuntauudistuksen vaikutuksista kuntiin. Valtiovarainministeriön julkaisu $11 \mathrm{a} / 2017$.

Ministry of Social Affairs and Health \& Ministry of Finance (2016). Fact sheet: Health, social services and regional government reform. Equal and cost-effective services for all. Retrieved from: http://alueuudistus.fi/documents/1477425/1892966/Fact+sheet+Health+social+service s+and+regional+government+reform++9_2016.pdf/0d3751dd-91bc-415c-bad5de54be1fa87a

Ministry of Transport and Communications, Ministry of Education, Ministry of Social Affairs and Health, Ministry of Employment and the Economy, Ministry of Finance \& Ministry of Environment \& Association of Finnish Local and Regional Authorities (2009). Arvio kaupunkiseutusuunnitelmien toteuttamisen etenemisestä.

Mäntysalo, R. (1999) Learning from the UK: Towards Market-oriented Land-use Planning in Finland. Housing, Theory and Society 16(4), 179-191.

Mäntysalo, R., Kangasoja, J. K., \& Kanninen, V. (2015) The paradox of strategic spatial planning: A theoretical outline with a view on Finland. Planning Theory \& Practice 16(2), 169-183.

Mäntysalo, R., Peltonen, L., Kanninen, V., Niemi, P., Hytönen, J. \& Simanainen, M. (2010) Keskuskaupungin ja kehyskunnan jännitteiset kytkennät. Viiden kaupunkiseudun yhdyskuntarakenne ja suunnitteluyhteistyö Paras-hankkeen käynnistysvaiheessa. ARTTU Studies 2. Acta Publications 217. Helsinki: Centre for Urban and Regional Studies and Association of Finnish Local and Regional Authorities. Retrieved from: http://shop.kunnat.net/uploads/p20100616132107082.pdf

Mäntysalo, R., Kallio, O., Niemi, P., Vakkuri, J., \& Tammi, J. (2012). Suuruuden ekonomiaa ja repaleisia kuntarakenteita: yhdyskunta- ja kustannusrakenteiden kytkentöjä Paraskaupunkiseuduilla. Kunnallistieteellinen aikakauskirja 40(4), 327-345.

Nyman, K. \& Mäntysalo, R. (2014) Patologisia piirteitä maakäyttö- ja rakennuslain sovelluksissa. Tapaus Savonlinnan Kasinonsaari. Kunnallistieteellinen aikakauskirja, 42(3), 324-339.

Olesen, K. (2014) The Neoliberalisation of strategic spatial planning. Planning Theory 13(3), 288-303. 
Prime Minister's Office (2015) Finland, a Land of Solutions. Strategic Programme of the Finnish Government. Retrieved from: http://valtioneuvosto.fi/documents/10184/1427398/Hallitusohjelma_27052015_final_ EN.pdf/f1071fae-a933-4871-bb38-97bdfd324ee6

Prusi, T. (2013) Kuntien itsehallinnollinen asema kaavoituksessa [Municipal Self-Governance in Planning] (Doctoral dissertation). Retrieved from: http://tampub.uta.fi/bitstream/handle/10024/68195/978-951-44-91818.pdf? sequence $=1 \&$ isAllowed=y University of Tampere, Tampere.

Purcell, M. (2009) Resisting neoliberalization: communicative planning or counterhegemonic movements? Planning Theory 8(2), 140-165. doi: $10.1177 / 1473095209102232$

Purcell, M. (2016) For democracy: Planning and publics without the state. Planning Theory 15(4), 386-401.

Puustinen S., Hirvonen J., Niemi P. \& Mäntysalo R. (2013). Selvitys alueidenkäytön suunnittelun ja ohjauksen voimavaroista. Reports of the Ministry of Environment 22/2013.

Puustinen, S., Mäntysalo, R., Hytönen, J. \& Jarenko, K. (2017). The “deliberative bureaucrat": deliberative democracy and institutional trust in the jurisdiction of the Finnish planner. Planning Theory and Practice 18(1), 71-88.

Puustinen, S., Mäntysalo, R. \& Jarenko, K. (2017) The Varying Interpretations of Public Interest: Making Sense of Finnish Urban Planners' Conceptions. Current Urban Studies, 5(1), 82-96.

Rannila, P. (2018) Relationality of the Law: On the Legal Collisions in the Finnish Planning and Land Use Practices. Journal of Planning Education and Research. Online publication ahead of print 29.6.2018. doi: 10.1177/0739456X18785443

Rhodes, R.A.W. (1994) The hollowing out of the state: The changing nature of the public service in Britain. Political Quarterly 65(2), 138-151.

Rodríguez-Pose, A. (2008). The rise of the "city-region" concept and its development policy implications. European Planning Studies 16:8, 1025-1046.

Sager, T. (2013). Reviving Critical Planning Theory: Dealing with pressure, neo-liberalism and responsibility in communicative planning. New York: Routledge.

Scott, A.J. (2001). Globalization and the rise of city-regions. European Planning Studies 9(7), 813-826. 
Smith, N. (1992). Contours of a spatialized politics: Homeless vehicles and the production of geographical scale. Social Text 33, 54-81.

Ward, K. and Jonas, A.E.G. (2004). Competitive city-regionalism as a politics of space: a critical reinterpretation of the new regionalism. Environment and Planning A 36, 2119-2139. 
${ }^{1}$ Excluding the Åland Islands.

${ }^{2}$ Excluding some sectoral state authorities that are able to make appeals on specific questions.

3 The multi-method case study (Hytönen 2016a) was conducted by the first author of the paper.

${ }^{4}$ The lack of expert resources in spatial planning cannot be ignored when assessing the capacities for democratically steered urban development. In the small municipalities, the resources are smallest also in relation to the size of the population (Puustinen et al., 2013).

${ }^{5}$ The evaluation's groundwork and report was written by the first author of this paper.

${ }^{6}$ The planned reform is justified by a perceived need to restructure the country's provision of social and health care services (Ministry of Social Affairs and Health \& Ministry of Finance, 2016). Currently, over 300 municipalities of different sizes provide these services. This mode of service provision has been deemed too expensive and inefficient in the face of an aging population and sharpening of centre-periphery structures. 